\title{
PENGARUH ORIENTASI PEMBELAJARAN DAN KONSEPSI BELAJAR TERHADAP PRESTASI AKADEMIK MAHASISWA TAHUN PERTAMA \\ Agatha Rizky $^{*}$, Clara R.P. Ajisuksmo ${ }^{2}$ \\ Fakultas Psikologi, Universitas Katolik Indonesia Atma Jaya \\ Email: Agatha.rizky@gmail.com ${ }^{\mathbf{1},} \underline{\text { clara.as@atmajaya.ac.id }}^{2}$
}

(C2019 -JPT Fakultas Psikologi Universitas Negeri Makassar. Ini adalah artikel dengan akses terbuka di

bawah licenci CC BY-NC-4.0 (https://creativecommons.org/licenses/by-nc/4.0/)

\begin{abstract}
This study aims to give an overview of learning orientation and learning conception on academic achievement of first year university students. learning orientation are the reason that motivates one to study, while learning conceptions are student's beliefs and views on learning and related phenomena, both are affective dimension known to influence the quality of learning. This study used a mixed-methods approach, quantitative and qualitative.Third semester psychology student $(\mathrm{N}=207)$ from private university filled out Inventarisasi Cara Belajar (Part B), theadapted translated versions of theInventory of Learning Styles, which used to measure learning orientation and student learning conceptions and their influence on academic achievement, which is seen through the Grade Point Average. Qualitative data is obtained through focus group discussions conducted in a group of students with high GPA and one group of students with a low GPA. The mean age of participants was 18,8 years with $11 \%$ males and $89 \%$ females. Data analysis using multiple regressionshowed, certificate directed variables, and ambivalent in learning orientation and cooperation variables in the conception of learning were able to predict student academic achievement with a negative correlation. Several other factors that influenced student academic achievement, including regulation of learning Self-regulation, peer influence, and leadership initiative.
\end{abstract}

\section{Keywords: Learning orientation; learning conception; Academic achievement}

ABSTRAK. Penelitian bertujuan untuk memperoleh gambaran pengaruh orientasi pembelajaran dan konsepsi belajar terhadap prestasi akademik mahasiswa tahun pertama. Orientasi belajar adalah alasan yang mendorong seseorang untuk belajar dan kuliah, sedangkan konsepsi pembelajaran adalah keyakinan dan pandangan tentang pembelajaran dan fenomena terkait, keduanya merupakan dimensi afektif proses belajar yang ikut menentukan kualitas hasil belajar mahasiswa.Penelitian ini menggunakan mixed method, yakni pendekatan kuantitatif dan kualitatif. Sebagai data kuantitatif sejumlah 207 mahasiswa semester tiga dari fakultas psikologi universitas swasta mengisi kuesioner Inventarisasi Cara Belajar (Bagian B) sebuah alat ukur adaptasi dari Inventory of Learning Styles. Inventarisasi Cara Belajar digunakan untukmengukur gambaran orientasi pembelajaran dan konsepsi belajar mahasiswaserta pengaruhnya terhadap prestasi akademis, yang dilihat melalui Indeks Prestasi Kumulatif. Data kualitatif diperoleh melalui diskusi kelompok terarah pada satu kelompok mahasiswa dengan IPK tinggi dan satu kelompokmahasiswa dengan IPK rendah.Usia rata-rata partisipan adalah 18,8 tahun, dengan $11 \%$ laki-laki dan $89 \%$ perempuan. Hasil analisis data menggunakan multiple regression menunjukkan bahwa variabel certificate directed, dan ambivalent dalam orientasi pembelajaran dan variabel cooperation dalam konsepsi belajar mampu memprediksi prestasi akademis mahasiswa dengan korelasi negatif. Beberapa faktor lain yang ditemukan memengaruhi prestasi akademis mahasiswa, di antaranya regulasi pembelajaran Self-regulation, Peer influence, dan Initiative Leadership. 


\section{PENDAHULUAN}

(2017) Pa PD Dikti $\begin{array}{r}\text { Pendidikan Tinggi } \\ \text { Kemenristekdikti }\end{array}$ menyebutkan total jumlah mahasiswa terdaftar di Indonesia sejumlah 6.924.511. Khususnya di provinsi D.K.I Jakarta terdapat 1.084.123 mahasiswa yang sedang menempuh pendidikan tinggi di 323 perguruan tinggi negeri dan swasta, dengan jumlah mahasiswa baru sebanyak 237.050 orang.

Undang-Undang No.12 tahun 2012 tentang Pendidikan Tinggi dalam Pasal 13 menyampaikan bahwa mahasiswa sebagai anggota Civitas Academica (kelompok/ komunitas /warga akademik) diposisikan sebagai insan dewasa yang memiliki kesadaran sendiri dalam mengembangkan potensi diri di Perguruan Tinggi untuk menjadi intelektual, ilmuwan, praktisi, dan/atau professional. Semakin meningkatnya jumlah mahasiswa yang terdaftar di Indonesia maka penelitianpenelitian untuk mengoptimalkan potensi diri mahasiswa di pendidikan tinggi harus terus dikembangkan.

Umumnya mahasiswa berada pada rentang usia 18 - 24 tahun, periode ini oleh Arnett (2007) disebut sebagai masa emerging adulthood, sebuah periode yang meliputi tahun-tahun dari sekolah menengah hingga pertengahan usia dua puluhan. Masa ini merupakan suatu tahapan perkembangan yang bukan merupakan tahapan remaja maupun tahapan dewasa awal meskipun tampak mirip, karena individu yang berada pada tahapan ini telah meninggalkan dependensi pada masa anak-anak dan remaja namun belum memiliki tanggung jawab seperti yang telah dimiliki oleh orang dewasa. Wood dkk. (2018) memandang periode emerging adulthood sebagai tahapan kritis pada perjalanan hidup individu.

Periode ini jika ditilik dari sudut pandang perkembangan kesehatan mental memiliki potensi untuk menjadi tahap perkembangan yang sangat positif. Individu yang berada pada fase emerging adulthood memiliki kesempatan yang lebih besar untuk memilih dan melakukan eksplorasi dalam kehidupan, tetapi juga mendapatkan tantangan yang lebih besar dengan tuntutan pembelajaran dan peranan sosial yang lebih tinggi. Hilangnya dukungan dan struktur yang awalnya didapatkan masa pendidikan menengah oleh sekolah dan keluarga, mendorong mahasiswa di masa emerging adulthood untuk lebih mengandalkan sumber dayanya sendiri dalam lingkungan yang kurang terstruktur.

Undang-undang menyebutkan bahwa mahasiswa diharapkan dapat memiliki kesadaran sendiri dalam mengembangkan potensi dirinya. Misra dan Castillo (2004) menyebutkan bahwa tuntutan akademik pada mahasiswa, di antaranya adalah tuntutan keluarga untuk berprestasi secara akademik, mengerjakan tugas kuliah, kompetisi dengan teman untuk mendapatkan penilaian yang baik, dan juga terkait perubahan sistem pendidikan yang lebih menuntut kemandirian.

Tuntutan untuk menyelesaikan tugastugas perkuliahan dengan baik untuk menunjukkan prestasi akademik, nampak masih menjadi salah satu fokus bagi mahasiswa. Utomo (Novanto \& Yulianti, 2015) menyatakan bahwa prestasi akademik adalah perolehan terbaik dalam semua disiplin akademik, baik pembelajaran dalam kelas maupun kegiatan ekstrakurikuler. Lebih spesifik lagi Peraturan Menteri Pendidikan dan Kebudayaan Republik Indonesia No. 49Tahun 2014 tentang Standar Nasional Pendidikan Tinggi dalam pasal 23 menyebutkan bahwa hasil penilaian capaian pembelajaran pada akhir program studi dinyatakan dengan indeks prestasi kumulatif (IPK) yang dihitung dengan cara menjumlahkan perkalian antara nilai huruf setiap mata kuliah yang ditempuh dan SKS mata kuliah bersangkutan dibagi dengan jumlah SKS mata kuliah yang diambil yang telah ditempuh.

Studi dalam konteks Asia telah menemukan bahwa pendekatan pembelajaran peserta didik lebih diarahkan pada pendekatan pembelajaran permukaan (surface learning) (Cheng, 2000; On, 1996; Watkins \& Biggs, 1996, dalam Santosa, 2017). On (1996) menemukan bahwa sistem pembelajaran di banyak Negara Asia, termasuk Cina, Jepang, dan Korea, terbukti melakukan praktik rote learning (sistem pembelajaran yang berfokus untuk menghafal fakta-fakta penting dan kurang memperhatikan makna dari materi yang dipelajari.

Hasil yang serupa juga ditemukan dalam konteks pembelajaran di Indonesia. Studi melaporkan bahwa dalam konteks pendidikan tinggi Indonesia, studi menunjukkan bahwa peserta didik daripada menggunakan pendekatan mendalam mereka lebih condong ke arah pendekatan permukaan untuk belajar termasuk menghafal (rote memorization), keterampilan berpikir kritis 
yang rendah, dan pembelajaran yang pasif, patuh, tidak reflektif (Ananda, 1997; Dardjowidjojo, 2001, 2006; Elsegood, 2006; Hadisaputra dan Santosa, 2008; Iftanti, 2012; Masduqi, 2011; Nilan, 2003; Pikkert dan Foster, 1996; Putrayasa, 2001; Santosa, 2008, 2012; Suharmanto, 2003, dalam Santosa, 2017).

Tidak hanya di tingkatan pendidikan menengah, beberapa temuan dari studi terhadap mahasiswa di pendidikan tinggi Indonesia juga masih cenderung menganggap untuk mendapatkan kesuksesan dalam konteks akademis memerlukan pendekatan tingkat permukaan (surface level) untuk belajar (Emilia \& Mulholland, 1991; Ismail, 2009; Santosa, 2013; Watkins, 1996, dalam Santosa; 2017).

Vermunt (Ajisuksmo, 1996) menggunakan analisis fenomenografi melalui wawancara terhadap mahasiswa di universitas yang menanyakan bagaimana cara mereka belajar dan sejauh mana ketergantungan mereka terhadap dosen dan mahasiswa lain dalam proses belajar, pandangan tentang belajar di universitas, dan harapan serta rencana studi mereka. Untuk mendalami proses pembelajaran mahasiswa Vermunt (1996, 1998; Busato et al. 1998; Boyle, et al. 2003; Vermunt, 2005) telah mengembangkan ILS (Inventory Learning styles) dalam menggambarkan hubungan antara pola belajar siswa dan variabel personal, kontekstual dan kinerja di dalam proses Self regulation learning. Konsep pola belajar seorang siswa didefinisikan oleh posisi siswa pada empat komponen pembelajaran: strategi pengolahan kognitif, strategi regulasi metakognitif, konsepsi belajar (conceptions of learning), dan orientasi pembelajaran (learning orientations). Yang kemudian secara khusus Ajisuksmo (1996) telah mengembangkan Inventarisasi Cara Belajar (ICB) sebagai adaptasi dari ILS.

Vermunt dan Donche (2017) menyampaikan bahwa dalam kerangka teori pola belajar, terdapat empat komponen pembelajaran mahasiswa yang terdiri dari: strategi pemrosesan kognitif (cognitive processing strategies), strategi regulasi metakognitif (metacognitive regulation strategies), konsepsi pembelajaran, dan motivasi atau orientasi belajar. Processing strategies adalah kombinasi aktivitas belajar kognitif yang digunakan mahasiswa untuk memproses materi pelajaran yang mana akan diarahkan untuk pembentukan pengetahuan, pemahaman, dan keterampilan. Regulation strategies adalah kombinasi aktivitas belajar metakognitif yang digunakan siswa dalam merencanakan, memantau, mengarahkan, dan mengevaluasi proses pembelajaran kognitif mereka dan yang secara tidak langsung mengarah untuk hasil belajar.

Konsepsi belajar (Conceptions of learning) adalah pandangan metakognitif dan keyakinan yang dimiliki mahasiswa tentang belajar, mengajar, dan fenomena yang terkait (Vermunt \& Donche, 2017). Pandangan seseorang terhadap belajar dapat mempengaruhi proses belajar dan pengaturan dalam belajar. Terdapat lima pandangan yang berbeda yaitu menerima pengetahuan (intake of knowledge), membentuk pengetahuan (construction of knowledge), menggunakan pengetahuan (use of knowledge), merangsang untuk belajar (stimulating education), dan kerjasama (cooperation). Konsepsi belajar menerima pengetahuan (intake of knowledge) melihat belajar sebagai kegiatan mengingat, menyimpan informasi sehingga dapat dikeluarkan kembali. Mahasiswa memandang bahwa pengetahuan sudah terdapat dalam buku atau guru. Konsepsi belajar membentuk pengetahuan (construction of knowledge) memandang belajar sebagai membentuk pengetahuan dan wawasan. Belajar merupakan tanggung jawab pribadi. Konsepsi belajar ketiga yaitu menggunakan pengetahuan (use of knowledge) memandang belajar sebagai usaha memperoleh fakta, ketrampilan, dan metode yang dapat digunakan saat diperlukan. Pada konsep merangsang untuk belajar (stimulating education), mahasiswa menganggap bahwa tugas belajar merupakan tanggung jawab dosen dan lembaga pendidikan untuk merangsang kegiatan belajar. Terakhir konsepsi belajar kerjasama (cooperation) dipandang sebagai kegiatan kerjasama antar mahasiswa.

Definisi dari orientasi pembelajaran (learning orientation) adalah orientasi mahasiswa terhadap belajar yang meliputi tujuan, sasaran, motif, dan kekhawatiran mahasiswa dalam kaitannya dengan studi mereka (Vermunt \& Donche, 2017). Cara seseorang belajar dan pendekatan yang dilakukan untuk belajar dapat dipengaruhi oleh motivasi. Motivasi dapat muncul dari dalam diri (intrinsik) maupun dari luar (ekstrinsik). Motivasi intrinsik terkait pada ketertarikan individu terhadap pelajaran (personally interested). Sedangkan motivasi eksternal 
terkait dengan penghargaan akademik (certificated), pencapaian profesional (vacational). Lalu ada dua orientasi lainnya yaitu menguji diri (self test) dan ambivalent. Orientasi pembelajaran berhubungan dengan tujuan, tekad, motivasi, ekspektasi, kekhawatiran, dan keraguan individu terhadap pembelajaran yang dilakukan. Oleh karena itu, orientasi pembelajaran dapat mempengaruhi mahasiswa dalam belajar dan mencapai tujuan pribadi.

Strategi pembelajaran yang digunakan mahasiswa untuk memproses materi pelajaran diregulasi oleh strategi metakognitif, yang mana pada gilirannya dipengaruhi oleh konsepsi mahasiswa terhadap belajar dan motivasi belajar. Pola pembelajaran ini mengarah pada hasil belajar, dan dipengaruhi oleh berbagai faktor personal dan kontekstual. Hasil pembelajaran dapat memberikan masukan untuk proses pembelajaran baru. Vermunt dan Vermetten (2004); Vermunt \& Donche (2017) berpendapat jika konteksnya berubah, pola belajar dapat juga berubah. Untuk menekankan sifat model yang dinamis, keseluruhan panah antar-elemen digambarkan dua arah. Hasil belajar siswa tidak akan mampu mengubah beberapa faktor pribadi seperti usia, namun faktor personal lain seperti kepercayaan tentang sifat dasar kecerdasan dapat memengaruhi cara mahasiswa belajar, maupun proses belajar mahasiswa.

Penelitian Vermunt (dalam Ajisuksmo, 1996) juga menghasilkan identifikasi empat strategi pemrosesan prototipikal atau 'gaya belajar' yaitu, meaning directed learning style, reproduction-directed learning style, application-directed learning style, dan undirected learning style.dengan masingmasing gaya dikaitkan dengan model mental karakteristik, orientasi pembelajaran, proses afektif dan strategi regulasi. Dua 'gaya' pertama berhubungan erat dengan deskripsi pendekatan mendalam (deep learning) dan permukaan (surface) untuk belajar, tetapi aplikasi dan cara belajar yang tidak diarahkan membawa fitur baru. Identifikasi siswa dengan kurangnya peraturan juga ditambahkan ke deskripsi belajar.

Vermunt dan Vermetten (Vermunt \& Donche, 2017) menyatakan bahwa suatu pola belajar dikonsep sebagai semua kegiatan pembelajaran yang saling terkait dan biasanya digunakan oleh pembelajar, hal-hal yang mereka yakini terkait proses pembelajaran, dan motivasi belajar mereka, yang mana keseluruhan hal tersebut dalam periode tertentu dapat membentuk karakteristik belajar mereka. Pola belajar adalah sebuah konsep koordinasi, yang merupakan sebuah hubungan timbal balik antara kognitif, afektif, kegiatan regulasi pembelajaran, kepercayaan terhadap belajar, dan motivasi belajar.

Menurut rangkuman Vermunt dan Vermetten (2004), sebagian besar hasil dari berbagai penelitian tersebut menunjukkan bahwa pola belajar tak terarah (undirected orientation) dan reproduktif (reproduction directed) tak terkait, atau justru berkorelasi negatif, dengan prestasi belajar. Sebaliknya, pola belajar berorientasi makna (meaning directed) dan aplikatif (application directed) berkorelasi positif dengan prestasi akademik.

Merujuk pada hasil penelitian sebelumnya, dapat dilihat bahwa terdapat korelasi yang signifikan antara orientasi pembelajaran dan konsepsi belajar terhadap prestasi akademik.Dengan dasar tersebut maka peneliti memiliki asumsi bahwa orientasi pembelajaran dan konsepsi belajar dapat memprediksi prestasi akademik mahasiswa tahun pertama. Yang kemudian perlu dilakukan kajian mendalam mengenai gambaran orientasi pembelajaran dan konsepsi belajar pada mahasiswa tahun pertama. Analisis lanjutan juga akan dilakukan untuk melihat apakah terdapat perbedaan orientasi pembelajaran dan konsepsi belajar yang dimiliki antara mahasiswa IPK tinggi dengan mahasiswa IPK rendah. Selain itu, peneliti akan menggali lebih lanjut faktor-faktor lain yang dapat mempengaruhi mahasiswa IPK tinggi dan mahasiswa IPK rendah dalam mencapai prestasi akademik.

\section{METODE}

Peneliti menggunakan pendekatan
kombinasi (mixed methods) yang menggunakan metode kuantitatif maupun kualitatif untuk memahami dan menjawab suatu rumusan permasalahan. Prioritas pengumpulan data pada penelitian ini mengikuti model eksplanatif, yaitu peneliti memprioritaskan pada pengumpulan data secara kuantitatif terlabih dahulu, kemudian data kualitatif. Kemudian menggunakan triangulation design yang menurut Creswell (2012) merupakan sebuah desain penelitian kombinasi yang bertujuan untuk memperoleh data yang berbeda tetapi saling melengkapi (complementary) untuk meneliti masalah penelitian dengan topik yang sama. Desain ini 
digunakan karena peneliti ingin membandingkan dan membedakan secara langsung terhadap hasil analisis statistik kuantitatif dengan temuan kualitatif atau untuk memvalidasi /mengekspansi hasil kuantitatif dengan data kualitatif.

Karakteristik partisipan dari penelitian ini adalah, untuk data kuantitatif melibatkan seluruh mahasiswa fakultas psikologi yang telah menjalani perkuliahan selama satu tahun, yakni mahasiswa semester III. Jumlah keseluruhan partisipan adalah 207 mahasiswa $(\mathrm{N}=207)$. Usia rata-rata partisipan adalah 18,8 tahun, dengan jumlah $11 \%$ laki-laki dan $89 \%$ perempuan. $90 \%$ partisipan memiliki IPK antara 3,00 hingga 4,00, sedangkan $10 \%$ partisipan memiliki IPK diantara 2,00 dan 3,00. Kemudian untuk pengumpulan data kualitatif, karakteristik partisipan yang terlibat adalah mahasiswa yang memiliki IPK tinggi (mahasiswa dengan rentang skor IPK 3,70 hingga 3,76) dan IPK rendah (mahasiswa dengan rentang skor IPK 2,40 hingga 2,74).

Selanjutnya dalam uji perbandingan orientasi pembelajaran dan konsepsi belajar yang dilakukan mahasiswa IPK tinggi dan mahasiswa IPK rendah, partisipan yang terlibat dalam uji perbandingan ini diambil dari 25\% mahasiswa dengan IPK tertinggi dan
$25 \%$ mahasiswa dengan IPK terendah dari total partisipan yang terkumpul. Hal ini ditujukan agar perbedaan yang terjadi antar dua kelompok dapat terlihat dengan lebih jelas. Dengan demikian, jumlah partisipan dalam uji perbandingan ini adalah sebanyak 104 mahasiswa, dengan 52 mahasiswa IPK tinggi dan 52 mahasiswa IPK rendah.

Kuesioner merupakan instrumen kuantitatif yang digunakan dalam penelitian ini. Adapun kuesioner yang digunakan berupa Inventarisasi Cara Belajar (ICB) yang diadaptasi dari Inventaris Leertijlen (ILS) oleh Ajisuksmo (1996). ICB disusun berdasarkan empat komponen dari self-regulated learning yang diungkapkan oleh Vermunt. Keempat kompenen ini dielaborasi dalam 16 sub-skala dan berisi 130 pernyataan. ICB terbagi ke dalam dua bagian, A dan B. Bagian A terdiri dari domain proses kognitif dan regulasi kognisi dalam belajar. Bagian B terdisi dari B1, yaitu orientasi pembelajaran dan B2, yaitu konsepsi belajar. Penelitian ini hanya menggunakan Bagian B dari ICB yang mengukur orientasi pembelajaran dan konsepsi belajar dalam proses pembelajaran. Kisi-kisi mengenai jumlah dan contoh item bagian $\mathrm{B}$ dari ICB dapat dilihat pada tabel 1.

\section{Tabel 1. Kisi-kisi Domain Inventarisasi Cara Belajar (ICB)}

\begin{tabular}{|c|c|c|c|}
\hline $\begin{array}{c}\text { Orientasi } \\
\text { Pembelajaran }\end{array}$ & $\begin{array}{c}\text { Jumlah } \\
\text { Item }\end{array}$ & Nomor Item & Contoh Item \\
\hline $\begin{array}{l}\text { Certificate } \\
\text { directed }\end{array}$ & 5 & $60,63,68,70,80$ & $\begin{array}{l}\text { Saya berusaha mencapai prestasi belajar yang } \\
\text { tinggi }\end{array}$ \\
\hline $\begin{array}{l}\text { Vocation } \\
\text { directed }\end{array}$ & 8 & $\begin{array}{l}56,62,67,71,73 \\
81,84,90\end{array}$ & $\begin{array}{l}\text { Ketika saya harus memilih, saya akan } \\
\text { mengambil mata kuliah yang tampaknya akan } \\
\text { berguna bagi profesi saya saat ini atau yang akan } \\
\text { datang }\end{array}$ \\
\hline Self test & 5 & $58,61,64,72,77$ & $\begin{array}{l}\text { Saya ingin membuktikan kepada diri saya } \\
\text { sendiri bahwa saya bisa mengikuti pelajaran di } \\
\text { perguruan tinggi }\end{array}$ \\
\hline $\begin{array}{l}\text { Personally } \\
\text { interested }\end{array}$ & 12 & $\begin{array}{l}57,65,69,74,78,82 \\
83,85,86,87,88,89 \\
\end{array}$ & $\begin{array}{l}\text { Saya belajar hanya karena saya tertarik pada } \\
\text { pokok-pokok masalah yang diuraikan }\end{array}$ \\
\hline Ambivalent & 5 & $59,66,75,76,79$ & $\begin{array}{l}\text { Saya ragu-ragu apakah bidang ilmu yang saya } \\
\text { pelajari merupakan bidang yang tepat bagi saya }\end{array}$ \\
\hline Konsepsi belajar & $\begin{array}{c}\text { Jumlah } \\
\text { Item }\end{array}$ & Nomor Item & Contoh Item \\
\hline $\begin{array}{l}\text { Intake of } \\
\text { knowledge }\end{array}$ & 9 & $\begin{array}{l}92,101,104,107 \\
110,113,116,117 \\
122\end{array}$ & $\begin{array}{l}\text { Dalam latihan dan tugas, saya lebih suka untuk } \\
\text { diberitahu dengan pasti apa yang harus saya } \\
\text { lakukan }\end{array}$ \\
\hline $\begin{array}{l}\text { Construction of } \\
\text { knowledge }\end{array}$ & 9 & $\begin{array}{c}95,96,98,102,106 \\
108,114,127,129\end{array}$ & $\begin{array}{l}\text { Bagi saya belajar berarti mencoba meninjau } \\
\text { masalah dari berbagai sisi dan menghubungkan }\end{array}$ \\
\hline
\end{tabular}




\begin{tabular}{lccl}
\hline $\begin{array}{c}\text { Orientasi } \\
\text { Pembelajaran }\end{array}$ & $\begin{array}{c}\text { Jumlah } \\
\text { Item }\end{array}$ & Nomor Item & \multicolumn{1}{c}{ Contoh Item } \\
\hline & & & $\begin{array}{l}\text { berbagai aspek yang sebelumnya tidak diketahui } \\
\text { ke dalam masalah tersebut }\end{array}$ \\
\hline $\begin{array}{l}\text { Use of } \\
\text { knowledge }\end{array}$ & 6 & $\begin{array}{c}91,100,105,112, \\
118,124\end{array}$ & $\begin{array}{l}\text { Apa yang saya pelajari harus bisa digunakan } \\
\text { untuk memecahkan masalah-masalah praktis }\end{array}$ \\
\hline $\begin{array}{l}\text { Stimulating } \\
\text { education }\end{array}$ & 8 & $\begin{array}{c}93,97,111,115, \\
120,123,126,128\end{array}$ & Dosen harus mendorong saya untuk belajar \\
\hline Cooperation & 8 & $\begin{array}{c}94,99,103,109, \\
119,121,125,130\end{array}$ & $\begin{array}{l}\text { Untuk menghadapi ujian, saya lebih baik belajar } \\
\text { bersama-sama teman lain }\end{array}$ \\
\hline
\end{tabular}

\section{HASIL DAN PEMBAHASAN}

Hasil

Sebelum analisis multiple regression dilakukan, korelasi antar masing-masing variabel prediktor dengan variabel dependen dianalisis terlebih dahulu. Hal ini untuk memprediksi sebuah variabel terhadap variabel lain, kedua variabel tersebut harus memiliki korelasi yang signifikan. Paparan korelasi antar variabel prediktor dengan variabel dependen dan interkorelasi antar variabel prediktor dapat dilihat pada tabel 2 .

Tabel 2. Interkorelasi Variabel (Korelasi Pearson)

\begin{tabular}{|c|c|c|c|c|c|c|c|c|c|c|c|}
\hline & IPK & $\begin{array}{l}\text { Certifi } \\
- \\
\text { cate } \\
\end{array}$ & $\begin{array}{l}\text { Voca- } \\
\text { tional }\end{array}$ & $\begin{array}{l}\text { Self } \\
\text { test }\end{array}$ & $\begin{array}{l}\text { Per- } \\
\text { sonal }\end{array}$ & $\begin{array}{l}\text { Ambi- } \\
\text { Valen } \\
t\end{array}$ & Intake & $\begin{array}{l}\text { Construct } \\
- \\
\text { ion } \\
\end{array}$ & $\begin{array}{l}\text { Use of } \\
\text { knowledg } \\
e\end{array}$ & $\begin{array}{l}\text { Stimu } \\
- \\
\text { lating } \\
\end{array}$ & $\begin{array}{l}\text { Coo- } \\
\text { peratio } \\
n \\
\end{array}$ \\
\hline IPK & 1.00 & $-.141 *$ & .106 & .015 & -.050 & $.174 *$ & -.114 & .077 & .101 & -.113 & $-.231 * *$ \\
\hline Certificate & $-.141 *$ & 1.00 & $\begin{array}{l}.318 * \\
*\end{array}$ & $\begin{array}{l}.356^{*} \\
*\end{array}$ & .081 & $\begin{array}{l}.230 * \\
*\end{array}$ & $\begin{array}{l}.444 * \\
*\end{array}$ & 0.48 & $.198 * *$ & $\begin{array}{l}.208 * \\
*\end{array}$ & $.201 * *$ \\
\hline Vocational & .106 & $.318 * *$ & 1.00 & $\begin{array}{l}.537 * \\
*\end{array}$ & $\begin{array}{l}.459 * \\
*\end{array}$ & $\begin{array}{l}- \\
.147 *\end{array}$ & $\begin{array}{l}.245^{*} \\
*\end{array}$ & $.288^{* * *}$ & $.520 * *$ & .091 & .096 \\
\hline Self test & .015 & $.356^{* *}$ & $\begin{array}{l}.537 * \\
*\end{array}$ & 1.00 & $\begin{array}{l}.356^{*} \\
*\end{array}$ & .026 & $\begin{array}{l}.317 * \\
*\end{array}$ & $.406 * *$ & $.407 * *$ & .109 & $.218 * *$ \\
\hline Personal & -.050 & .081 & $\begin{array}{l}.459 * \\
*\end{array}$ & $\begin{array}{l}.356^{*} \\
*\end{array}$ & 1.00 & -.060 & $.161 *$ & $.509 * *$ & $.426 * *$ & $\begin{array}{l}.195 * \\
*\end{array}$ & .059 \\
\hline Ambivalent & $-.174 *$ & $.230 * *$ & $-.147 *$ & .026 & -.060 & 1.00 & $\begin{array}{l}.313^{*} \\
*\end{array}$ & $-.138 *$ & -.040 & $\begin{array}{l}.312 * \\
*\end{array}$ & $.139 *$ \\
\hline Intake & -.114 & $.444 * *$ & $\begin{array}{l}.245^{*} \\
*\end{array}$ & $\begin{array}{l}.317 * \\
*\end{array}$ & $.161 *$ & $\begin{array}{l}.313^{*} \\
*\end{array}$ & 1.00 & .132 & $.371 * *$ & $\begin{array}{l}.660 * \\
*\end{array}$ & $.398 * *$ \\
\hline $\begin{array}{l}\text { Constructio } \\
n\end{array}$ & .077 & 0.48 & $\begin{array}{l}.288 * \\
*\end{array}$ & $\begin{array}{l}.406^{*} \\
*\end{array}$ & $\begin{array}{l}.509 * \\
*\end{array}$ & $-138^{*}$ & .132 & 1.00 & $.401 * *$ & .030 & $.139 *$ \\
\hline $\begin{array}{l}\text { Use of } \\
\text { knowledge }\end{array}$ & .101 & $.198 * *$ & $\begin{array}{l}.520^{*} \\
*\end{array}$ & $\begin{array}{l}.407 * \\
*\end{array}$ & $\begin{array}{l}.426^{*} \\
*\end{array}$ & -.040 & $\begin{array}{l}.371 * \\
*\end{array}$ & $.401 * *$ & 1.00 & $\begin{array}{l}.184 * \\
*\end{array}$ & $.183 * *$ \\
\hline Stimulating & -.113 & $.208 * *$ & .091 & .109 & $\begin{array}{l}.195^{*} \\
*\end{array}$ & $\begin{array}{l}.312 * \\
*\end{array}$ & $\begin{array}{l}.660 * \\
*\end{array}$ & .030 & $.184 * *$ & 1.00 & $.315 * *$ \\
\hline $\begin{array}{l}\text { Cooperatio } \\
n\end{array}$ & $\begin{array}{l}- \\
*\end{array}$ & $.201 * *$ & .096 & $\begin{array}{l}.218^{*} \\
*\end{array}$ & .059 & $.139 *$ & $\begin{array}{l}.398^{*} \\
*\end{array}$ & $.139 *$ & $.184 * *$ & $\begin{array}{l}.315^{*} \\
*\end{array}$ & 1.00 \\
\hline
\end{tabular}

$\mathrm{N}=207 ; *$ : Korelasi signifikan pada $0.05(\mathrm{p}<0.05) ; * *$ : Korelasi signifikan pada $0.01(\mathrm{p}<0.01)$

Berdasarkan uji korelasi Pearson antar variabel prediktor dengan variabel dependen (IPK), terlihat bahwa variabel certificate memiliki korelasi negatif yang signifikan dengan IPK $(\mathrm{r}=-0.141$, $\mathrm{p}<0.05)$. Kemudian, variabel ambivalent memiliki korelasi negatif yang signifikan dengan IPK $(\mathrm{r}=-0.174 . \mathrm{p}<0.05)$. Terakhir, variabel cooperation memiliki korelasi negatif yang signifikan dengan IPK $(\mathrm{r}=-0.231, \mathrm{p}<0.01)$.

Berdasarkan hasil analisis korelasi yang diperoleh, dapat disimpulkan bahwa terdapat tiga variabel prediktor yang berkorelasi signifikan dengan variabel dependen IPK yaitu, certificate directed, ambivalent, dan cooperation. Maka hanya ketiga variabel itulah yang akan dilibatkan dalam analisis multiple regression. 
Berdasarkan hasil multiple regression yang dilakukan, dapat dilihat bahwa nilai F-ratio yang diperoleh adalah 5.782, dengan $\mathrm{p}<0.05$. Dengan demikian, dapat disimpulkan bahwa model regresi yang dihasilkan dapat memprediksi IPK secara signifikan, yakni model cooperation, ambivalent, dan certificate dapat memprediksi IPK mahasiswa tahun pertama Fakultas Psikologi secara signifikan. Model regresi yang dihasilkan memberikan nilai $\mathrm{R}^{2}$ sebesar 0.079.Dengan demikian, dapat dikatakan bahwa semua variabel prediktor dapat memprediksi $7.9 \%$ variasi dari skor IPK.

Analisis data tambahan dilakukan dengan tujuan untuk mengetahui apakah terdapat perbedaan certificate, vocational, self test, personal, ambivalent, intake, construction, use of knowledge, stimulating, dan cooperation yang signifikan antara mahasiswa IPK tinggi dan mahasiswa IPK rendah. Dalam uji perbandingan orientasi pembelajaran dan konsepsi belajar yang dilakukan mahasiswa IPK tinggi dan mahasiswa IPK rendah, 104 partisipan yang terlibat dalam uji perbandingan ini diambil dari $25 \%$ mahasiswa dengan IPK tertinggi $(\mathrm{N}=52)$ dan $25 \%$ mahasiswa dengan IPK terendah $(\mathrm{N}=52)$.

Hasil analisis menunjukkan bahwa seluruh variabel dalam Orientasi pembelajaran, certificate, vocational, selftest, personal, Ambivalent, tidak menunjukkan adanya perbedaan yang signifikan antara kelompok mahasiswa IPK tinggi dan IPK rendah. Dalam hal konsepsi belajar, empat variabel menunjukkan bahwa tidak terdapat perbedaan yang signifikan pada Intake, Construction, Use of knowledge, dan antara kelompok mahasiswa IPK tinggi dan mahasiswa IPK rendah.Perbedaan yang signifikan antara kelompok mahasiswa IPK tinggi dan mahasiswa IPK rendah hanya terlihat pada variabel Cooperation ( $p$ value $0.013, \mathrm{p}<0.05$ ).

\section{Pembahasan}

Berdasarkan hasil analisis yang dilakukan, ditemukan bahwa dalam orientasi pembelajaran, vocational directed merupakan orientasi pembelajaran yang paling banyak dimiliki oleh partisipan. Dalam hal konsepsi belajar, partisipan paling sering menggunakan use of knowledge dalam membentuk konsepsi belajarnya. Kombinasi komponen orientasi pembelajaran dan konsepsi belajar ini dapat ditemukan dalam pola belajar application directed, yang menurut Vermunt dan Donche (2017) dapat didefinisikan sebagai perilaku ketika mahasiswa mencoba untuk menemukan hubungan antara apa yang mereka pelajari dengan dunia luar. Mahasiswa mencoba untuk menemukan contoh dari apa yang mereka pelajari dan berpikir tentang bagaimana mereka dapat menerapkan apa yang mereka pelajari dalam praktik seharihari. Lebih lanjut dijelaskan oleh Vermunt dan Donche (2017) bahwa dengan pola belajar ini umumnya mahasiswa secara bersamaan mampu melakukan regulasi terhadap diri sendiri (self-regulated) dan memiliki dorongan regulasi secara eksternal (externally regulated). Hal umum lainnya adalah mahasiswa dengan pola belajar ini mementingkan faktor apakah pengetahuan mereka peroleh dapat digunakan, di sisi lain pengetahuan yang tidak dapat mereka gunakan tidak akan bernilai banyak bagi mereka. Yang terakhir adalah bahwa vocational motives sering mendasari pembentukan pola ini, dimana mahasiswa ingin mempersiapkan diri untuk suatu profesi tertentu atau mereka ingin menjadi lebih baik dalam pekerjaan yang saat ini sedang dilakukan.

Berdasarkan hasil analisis multiple regression, dari sepuluh variabel hanya tiga variabel yaitu cooperation, certificate directed, dan ambivalent yang dapat memprediksi prestasi akademis partisipan. Sedangkan intake of knowledge, construction of knowledge, use of knowledge, stimulating education, vocation directed, self-test, dan personally interested ditemukan tidak dapat 
memprediksi prestasi akademik. Mengenai keterkaitan antara konsep tentang pembelajaran, pendekatan belajar, dan hasil belajar dikemukakan (Ajisuksmo, 1996; Purwanti, 2006) bahwa sebenarnya tidak ada satupun konsep belajar yang salah dan tidak mempengaruhi hasil belajar. Namun kombinasi konsep pembelajaran construction of knowledge dan use of knowledge akan mengarahkan individu untuk menggunakan cara-cara belajar yang merupakan ciri pendekatan belajar mendalam, yang selanjutnya secara teoritik hasil belajar mahasiswa yang menggunakan pendekatan belajar mendalam (deep approach) lebih optimal dan lebih sesuai dibandingkan dengan hasil belajar yang menggunakan pendekatan belajar lain.

Terkait dengan pendapat ini walau analisa kuantitatif menunjukkan bahwa construction of knowledgedanuse of knowledgetidak dapat secara signifikan memprediksi prestasi akademik, namun dalam hasil analisa kualitatif ditemukan bahwa seluruh partisipan dengan IPK tinggi menggunakan konsepsi belajar construction of knowledge dan use of knowledge, sedangkan pada partisipan IPK rendah hanya use of knowledge saja. Dalam studi empiris terhadap mahasiswa fakultas kedokteran di srilanka, (Marambe et al., 2007) menunjukkan bahwa kualitas pengetahuan yang diperoleh dengan konstruksi pengetahuan aktif (active construction of knowledge) lebih baik, lebih mudah diakses, selaras dan dapat digunakan daripada pengetahuan yang diperoleh dengan cara pasif.

Hasil analisa model regresi menyatakan bahwa ketiga variabel yaitu cooperation, certificate directed,dan ambivalent ditemukan memberikan kontribusi negatif signifikan terhadap prestasi akademis. Data ini menyatakan bahwa, ketika mahasiswa semakin menekankan certificate directed, dan bersikap ambivalent dalam menentukan orientasi pembelajarannya, serta memiliki cooperation sebagai konsepsi belajar, maka semakin rendah pula prestasi akademis yang dicapainya.
Pada perbandingan antara kelompok partisipan IPK tinggi dan IPK rendah, data menunjukkan adanya perbedaan yang signifikan pada konsepsi belajar cooperation, dimana mahasiswa IPK rendah memiliki skor yang lebih tinggi dibandingkan mahasiswa IPK tinggi. Vermunt dan Vermetten (2004) menyebutkan bahwa dengan konsepsi belajar cooperation, mahasiswa memandang bahwa belajar adalah kegiatan belajar bersama-sama siswa lain dan bukan tanggung jawab siswa sendiri. Mahasiswa berkeyakinan bahwa dengan belajar bersama siswa lain, ia dapat belajar sesuatu dan menarik keuntungan dari siswa lain. Ada kemungkinan bahwa sebagian siswa dengan konsep ini memanfaatkan kegiatan belajar untuk sosialisasi.

Menurut penelitian Purwanti (2006) terhadap mahasiswa perguruan tinggi negeri dan perguruan tinggi swasta menyatakan bahwa jenis pendekatan belajar mengejar prestasi (achieving approach) dipengaruhi oleh jenis konsep pembelajaran kerjasama (cooperation) dan konsep diri akademik. Menurut Lai Peng dan Bettens (Purwanti, 2006), fokus mahasiswa yang menggunakan pendekatan belajar mengejar prestasi adalah memperoleh nilai setinggi mungkin, dan untuk mencapai tujuan tersebut sangat mungkin berbagai strategi digunakan. Dapat dikatakan bahwa mahasiswa dengan pendekatan belajar mengejar prestasi memiliki keterlibatan erat pada tugas yang dihadapi meskipun keterlibatannya ini hanyalah merupakan alat untuk mencapai nilai yang tinggi.

Beberapa faktor lain ditemukan memengaruhi prestasi akademis partisipan. Hasil analisa kualitatif menemukan faktor internal yang tampak memengaruhi prestasi akademis partisipan adalah regulasi pembelajaran dan initiative leadership. Tead (Winston \& Patterson, 2006) menyatakan kepemimpinan adalah kegiatan memengaruhi orang-orang agar mereka mau bekerja sama untuk mencapai tujuan yang diinginkan. Respon ketiga partisipan 
IPK tinggi pada saat diskusi terkait solusi ketika menghadapi permasalahan pada proses pembelajaran, khususnya dalam pengerjaan tugas kelompok. Ketiga partisipan IPK tinggi mampu memunculkan inisiatif memimpin, yang dimulai dari inisiatif membuat group chat, kemudian baik secara halus maupun dengan spesifik menentukan tugas bagi masing-masing anggota kelompok, melakukan organisir, dan memantau pengerjaan hingga tugas selesai.Perilaku ini tidak muncul dalam kelompok IPK rendah dimana partisipan justru menunjukkan bahwa dukungan teman adalah salah satu faktor yang mendorong meraka untuk belajar.

\section{KESIMPULAN}

Tujuan dari penelitian ini adalah untuk mengetahui gambaran orientasi pembelajaran dan konsepsi belajar pada mahasiswa tahun pertama.Hasil analisa menunjukkan bahwa vocational directed merupakan orientasi pembelajaran yang paling banyak dimiliki oleh partisipan. Dalam hal konsepsi belajar, partisipan paling sering menggunakan use of knowledge dalam membentuk konsepsi belajarnya.

Selain itu, penelitian ini juga bertujuan untuk mengetahui prediksi dan kontribusi dari orientasi pembelajaran dan konsepsi belajar terhadap prestasi akademik mahasiswa tahun pertama.Berdasarkan hasil analisis multiple regression, dari sepuluh variabel hanya tiga variabel yaitu cooperation, certificate directed, dan ambivalent yang dapat memprediksi prestasi akademis partisipan. Sedangkan intake of knowledge, construction of knowledge, use of knowledge, stimulating education, vocation directed, self-test, dan personally interested ditemukan tidak dapat memprediksi prestasi akademik.

Model regresi menyatakan bahwa ketiga variabel yaitu cooperation, certificate directed, dan ambivalent ditemukan memberikan kontribusi negatif signifikan terhadap prestasi akademis. Data ini menyatakan bahwa, ketika mahasiswa semakin menekankan certificate directed, dan bersikap ambivalent dalam menentukan orientasi pembelajarannya, serta memiliki cooperation sebagai konsepsi belajar, maka semakin rendah pula prestasi akademis yang dicapainya.

Hasil uji perbedaan orientasi pembelajaran dan konsepsi belajar antar mahasiswa IPK tinggi dan mahasiswa IPK rendah menunjukkan bahwa tidak ada perbedaan yang signifikan pada orientasi pembelajaran certificate directed, vocational directed, self-test, personally interested, dan ambivalent, pada mahasiswa IPK tinggi dan IPK rendah. Kemudian pada konsepsi belajar, keempat variabel yaitu intake of knowledge, construction of knowledge, use of knowledge, dan stimulating juga menunjukkan tidak adanya perbedaan yang signifikan pada mahasiswa IPK tinggi dan IPK rendah. Namun, data menunjukkan adanya perbedaan yang signifikan pada cooperation, dimana mahasiswa IPK rendah memiliki skor yang lebih tinggi dibandingkan mahasiswa IPK tinggi.

Sedangkan beberapa faktor lain ditemukan memengaruhi prestasi akademis partisipan. Hasil analisa kualitatif menemukan faktor internal yang tampak memengaruhi prestasi akademis partisipan adalah regulasi pembelajaran dan initiative leadership. Kemudian, peer influence ditemukan sebagai faktor eksternal yang memengaruhi prestasi akademis baik pada partisipan IPK tinggi maupun partisipan IPK rendah.

Pada kesempatan selanjutnya, diharapkan dapat dilakukan penelitian lanjutan untuk mengukur sumbangan atau kontribusi proses belajar dan regulasi pembelajaran terhadap prestasi akademis.Apabila penelitian selanjutnya bermaksud untuk mengukur kontribusi proses belajar dan regulasi pembelajaran terhadap prestasi akademis, ada baiknya jika variabel orientasi pembelajaran dan konsepsi belajar juga kembali diukur untuk melihat dinamika yang terjadi diantara keempat variabel tersebut. 
Mengingat hasil penelitian yang menunjukkan bahwa seluruh variabel orientasi pembelajaran dan konsepsi belajar dapat memberikan kontribusi sebesar $7.9 \%$ variasi dari skor IPK . Pada penelitian selanjutnya akan lebih baik jika peneliti mempertimbangkan variabel faktor personal dan faktor kontekstual dalam pengolahan data. Misalnya: usia, jenis kelamin, atau latar belakang pendidikan sebelumnya.

\section{DAFTAR PUSTAKA}

Ajisuksmo, C. R. P. (1996). Self-regulated learning in Indonesian higher education. Doctoralthesis, Tilburg University, The Netherlands \& Atma Jaya Catholic University,Indonesia.

Arnett, J. J. (2007). Emerging adulthood: What is it, and what is it good for?. Child development perspectives, 1(2), 68-73.

Creswell, J.W. (2012). Educational research: Planning, conducting, and evaluating quantitative qualitative research 4th edition. New York: Pearson.

Marambe, K. N., Athuraliya, T. N., Vermunt, J. D., \& Boshuizen, H. P. (2007). A comparison of learning strategies, orientations and conceptions of learning of first-year medical students in a traditional and an innovative curriculum.

Misra, R., \& Castillo, L. G. (2004). Academic stress among college students: Comparison of American and international students. International Journal of Stress Management, 11(2), 132.

Novanto, Y., \& Yulianti, L. (2015). Faktor-faktor yang berkaitan dengan prestasi akademik mahasiswa sekolah tinggi teologi" x". Tanjung Balai: Sekolah Tinggi Teologia Marturia.

On, L. W. (1996). The cultural context for Chinese learner: Conceptions oflearning in the Confucian tradition. In D. A. Watkins \& J. B. Biggs (Eds.),The Chinese Learner: Cultural, Psychological, and
Contextual Influences (pp.25-41).

Hong Kong/Melbourne:

Comparative Education

ResearchCentre/Australian Council for Educational Research.

Peraturan Menteri Pendidikan dan Kebudayaan Republik Indonesia No. 49 Tahun 2014. Tentang Standar Nasional Pendidikan Tinggi. Diunduh pada Desember 2018 di http://faperta.ugm.ac.id/2014/site/fok us/pdf/permen_tahun2014_nomor04 9.pdf

Purwanti, M. (2006). Peran Pengajaran Dosen, Konsep Pembelajaran, Konsep Diri Akademik dan Pendekatan Belajar Dalam Menentukan Hasil belajar. Disertasi. Depok: $\quad$ Fakultas Psikologi Universitas Indonesia.

Santosa, M. H. (2017). Learning approaches of Indonesian EFL gen z students in a flipped learning context. Journal on English as a Foreign Language, 7(2), 183-208.

Statistik Pendidikan Tinggi. (2017). Jakarta: Pusdatin Iptek Dikti, Setjen, Kemenristekdikti. Diunduh pada Desember 2018 di: https://ristekdikti.go.id/epustaka/buk u-statistik-pendidikan-tinggi-2017/

Undang-Undang Republik Indonesia Nomor 12 Tahun 2012. Tentang Pendidikan Tinggi. Diunduh pada Desember $2018 \quad$ di http://diktis.kemenag.go.id/prodi/dok umen/UU-Nomor-12-Tahun-2012ttg-Pendidikan-Tinggi.pdf

Vermunt, J.D., \& Donche, V. (2017).A learning patterns perspective on student learning in higher education: state of the art and moving forward. Educ Psychol Rev, 29:269-299

Vermunt, J. D. (2005). Relations between student learning patterns and personal and contextual factors and academic performance. Higher education, 49(3), 205.

Vermunt, J. D., \& Vermetten, Y. J. (2004). Patterns in student learning: Relationships between learning strategies, conceptions of learning, 
and learning orientations. Educational psychology review, 16(4), 359-384.

Winston, B. E., \& Patterson, K. (2006). An integrative definition of leadership. International journal of leadership studies, 1(2), 6-66.
Wood D. et al. (2018) Emerging Adulthood as a Critical Stage in the Life Course. In: Halfon N., Forrest C., Lerner R., Faustman E. (eds) Handbook of Life Course Health Development. Springer, Cham. 